\title{
Effects of Predisposing, Enabling, and Reinforcing Factors on the Uptake of Voluntary Counselling and Testing among Female Sex Workers in Grobogan, Central Java
}

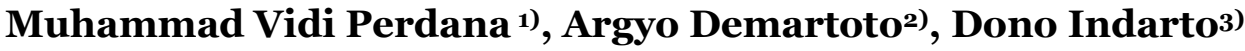 \\ 1)Masters Program in Public Health, Sebelas Maret University \\ 2) Faculty of Social and Political Sciences, Sebelas Maret University \\ 3) Department of Physiology, Faculty of Medicine, Sebelas Maret University
}

\begin{abstract}
Background: Human Immunodeficiency Virus (HIV) infection is a global public health issue. Global AIDS Response Progress Reporting (GARP) reported that in 2015, about 36.7 million people worldwide suffered from HIV-AIDS in all age groups. The highest number of HIV/AIDS cases occured in East Africa and South Africa. This study aimed to examine the effects of predisposing, enabling, and reinforcing factors on the uptake of voluntary counselling and testing (VCT) among female sex workers in Grobogan, Central Java.

Subjects and Method: This was an analytical observational study with cross-sectional design. It was conducted in Grobogan, Central Java, in July 2017. A sample of 142 female sex workers were selected for this study by exhaustive sampling. The dependent variable was uptake of VCT. The independent variables were attitude, perceived benefit, external motivation from others, and social support. The data were collected by a questionnaire and analyzed by multiple logistic regression.

Results: Positive attitude towards HIV status ( $\mathrm{OR}=6.09 ; 95 \% \mathrm{CI}=0.97$ to $38.38 ; \mathrm{p}=0.054)$, positive perceived benefit $(\mathrm{OR}=10.58 ; 95 \% \mathrm{CI}=1.48$ to $76.93 ; \mathrm{p}=0.019)$, external motivation $(\mathrm{OR}=$ 8.30; $95 \% \mathrm{CI}=1.21$ to $56.82 ; \mathrm{p}=0.031)$, and social support $(\mathrm{OR}=9.45 ; 95 \% \mathrm{CI}=1.46$ to $60.83 ; \mathrm{p}=$ o.018), positively affected uptake of VCT.

Conclusion: Positive attitude towards HIV status, positive perceived benefit, external motivation, and social support, positively affect uptake of VCT.
\end{abstract}

Keywords: HIV, Voluntary Counselling Testing, female sex workers

\section{Correspondence:}

Muhammad Vidi Perdana. Masters Program in Public Health, Sebelas Maret University, Jl. Ir. Sutami 36 A, Surakarta 57126, Central Java. Email: vidihse@gmail.com.

Mobile: +6289673200639 .

\section{BACKGROUND}

Infeksi Human Immunodeficiency Virus (HIV) is still a global public health issue. Based on reports of several sources, HIV/ AIDS epidemic in the world is classified as apprehensive. The data of Global AIDS Response Progress Reporting (GARP) 2016 showed that until 2015 there are about 36.7 million people around the world who were diagnosed with HIV/AIDS in all groups of age, with the highest cases occurred in East and South Africa with a total of 19.0 million people. WHO and UNAIDS reported that there were three countries in Asia that were on HIV infection points namely China, India, and Indonesia, in which all of three had the biggest population in the world. Indonesia was the third highest HIV cases in Asia with $13 \%$ of all cases (UNAIDS, 2013). The cumulative number of HIV/ AIDS cases recorded from 1987 until March 2016 were 191,073 people with HIV and 77,940 people with AIDS (Kemenkes RI, 2016). The data indicated the gigantic risk for getting HIV faced by the population group in Indonesia from all ages. 
HIV/AIDS transmission in Indonesia is still concentrated on Injecting Drug Users (IDU), men who have sex with men, and sex workers (both heterosexual and homosexual) along with the customers as well as their permanent sex partners (KPA Nasional, 2009). Based on the data from Ministry of Health of the Republic of Indonesia (2016), the risk factor of HIV/ AIDS through heterosexual sex was still the strongest factor $(51,692)$ followed by homobisexual factor $(2,304)$, IDU $(8,835)$, blood transfusion (201), perinatal transfusion $(2,226)$ and other unknown factors $(12,398)$. There are 34 provinces in Indonesia and as many as 511 regencies or cities reported HIV/AIDS cases. It proves that there is no single province that is declared as free of HIV/AIDS cases. It is even estimated that HIV/AIDS has hit more than a half Regencies/ Cities in Indonesia. Based on the official data from the Ministry of Health in 2016, several Provinces in Indonesia one of them was Central Java Province, had quite significant number of people who were living with HIV/AIDS. With a total of about 13,547 people with HIV and 5,049 people with AIDS. The number was spread in the entire region of Central Java Province.

Based on the preliminary study conducted in December 2016, Grobogan Regency was in the forth rank in Central Java Province following the City of Semarang, Sragen Regency, and Banyumas Regency. In Grobogan Regency there were various sexual service facilities (red light districts) and night life entertainment facilities known as "Gunungrejo" HIV/ AIDS in Grobogan Regency was firstly discovered in 2002 as many as 4 cases. However the extremely significant change was reported by HIV/AIDS statistics data until the end of December 2016, cumulatively the number of patients were likely to be escalating to
858 cases. The ratio of HIV cases between male and female was $37 \%$ and $63 \%$ respectively.

Based on above matter, HIV/AIDS becomes public health issue that involves all aspects of life, medically, psychologically, socially and culturally. There are various policies and programs offered by the government as HIV/AIDS countermeasure. One of the government policies in the countermeasure of HIV/ AIDS cases is the President of the Republic of Indonesia's Regulation no. 75/2006 mandating the establishment of AIDS Countermeasure Commission (KPA) in National level, Province level and Regency level along with its secretariat in order to improve AIDS prevention and countermeasure efforts to be more intensive, thoroughly, integrated, and responsible to all regions. Furthermore, the government also gives various healthcare facilities among others are blood safety, information education and communication (IEC) especially Voluntary Counseling and Testing (VCT) program

VCT service includes pre-test counseling, HIV test, and post-test counseling, based on individual voluntary or awareness. Counseling components should be based on confidentiality, and cover the information about HIV transmission and personal discussion on individual risks that allow one to make decision about HIV/AIDS test and the risk they will face, so that VCT has good benefits for individual as well as the society (WHO, 2003). Pre-test counseling provides knowledge about HIV and the benefits of HIV test, the decision making for the test, and HIV planning to be faced. Post-test counseling helps someone to understand and accept the HIV status and refers to support service. Couseling is conducted by a counselor who is an experienced health worker with clients who feel that they have high risk for HIV/AIDS and 
also conducted in confidential and voluntary manner (Depkes RI, 2004).

VCT service program has an effect as the potential prevention of HIV transmission and functions as HIV/AIDS-related providing program for countermeasure service. VCT is meant to help society, especially risk populations and their family members, recognizing their health status related to HIV, in which the result may be used as motivation for transmission prevention effort and shortly may obtain healthcare service as appropriate. The target of VCT service is extremely wide which is people with highest risk for getting infected such as sex workers, gay, drugs users, and prisoners. Based on the data on VCT visits of Grobogan Regency in the second semester of 2016, Female Sex Workers were in the first rank who conduct HIV/AIDS prevention efforts with a total of $31 \%$ of the entire VCT visits in high risk groups. Female Sex Workers are likely to have numerous sex partners. Kartono (2011) explained female sex workers as a phenomenon of women selling themselves, body, dignity, and personality to numerous people for satisfying sexual desires with payment reward.

Based on Regional Regulation of Grobogan Regency No.4/2014 on the subject of HIV/AIDS Countermeasure article 8 and 9 mentions that every who is at risk for HIV and STI infection should have their health examined in VCT and STI clinics. Comprehensively, the government, particularly Health Office of Grobogan Regency (2016) has conducted more concrete activities by implementing socialization and early examination for society through STI, VCT, CST and PMTCT clinics. According to a study conducted by World Bank Global HIV/AIDS Program (2008) stated that to reduce and resist the transmission effect of HIV/AIDS epidemic, the government of Ethiopia implements policy for each citizen who is at risk for HIV/AIDS infection to commit VCT. The stipulation on VCT is a very important matter for a country in HIV/AIDS prevention program. (Onokerhoraye et al, 2012). Whereas according to Alao (2004) VCT is a key to identify whether someone suffer from HIV/AIDS and later will obtain further treatment.

Related to HIV/AIDS prevention and countermeasure, there are several parties who have relatively big influence, such as some NGOs that concern by committing assistance on HIV/AIDS prevention and countermeasure, pimps who are directly responsible in providing the accommodation to self hawking for female sex workers also discuss the problems faced by sex workers, the influence of fellow female sex workers in joining activities. In female sex workers setting there are various factors that influence sex worker to commit VCT periodically, either from the internal such as efficacy and evaluation over VCT experience or external influence such as people met everyday such as pimps, fellow sex workers, customers and outreach officers. The practice of service and resources availability in VCT clinic also may influence the female sex workers to commit VCT.

The study toward issue of HIV/AIDS prevention through VCT is important to conduct for analyzing predisposition, enabling, and reinforcing factors that influence Female Sex Workers in Grobogan Regency to commit VCT.

\footnotetext{
SUBJECTS AND METHOD

\section{Design of the Study}

The study was analytic observational study with cross sectional approach that emphasized on the data collection process on independent and dependent variables that was conducted only once at the same time
} 
(Murti B, 2013). The approach aimed to explain how big the influence of predisposition, enabling and reinforcing factors toward VCT among Female Sex Workers in Grobogan Regency.

\section{Population and Sample}

In general the population of the study was the entire Female Sex Workers in Grobogan Regency, whereas the target population was the members of Female Sex Workers community in Gunung Rejo, Grobogan Regency with an estimation of 142 people.

Subjects of the study were members of Female Sex Workers community that was located in Gunung Rejo, Grobogan Regency with a total of 142 people, selected by using total sampling technique.

\section{Instrument of the Study}

Data collection instrument of the study was questionnaires. Data collection was conducted directly by the researcher by means of observation.

\section{Operational Definition}

Operational definition of perceived benefit on VCT was the study subjects' determination by believing that HIV/AIDS counseling and testing (VCT) would give benefits to the respondents.

Attitude from the values obtained by identifying the HIV/AIDS status was study subjects' perception about the changes happened to Female Sex Workers as the result of HIV/AIDS status. Motivation to follow other people's encouragement.

Others' support was the intention of study subjects to follow the encouragement, suggestion, orders from other people to commit VCT. Service of VCT clinic practice was service of practice given by VCT clinics for clients from registration, pre-test counseling, HIV/AIDS test, post-test counseling.
Service environment of VCT clinic was VCT clinic environment that gave comfort and the availability of support capacity for HIV/AIDS counseling and testing's smoothness.

\section{Data Analysis}

Data analysis technique used were univariate, bivariate, multivariate analysis. Univariate analysis aimed to explain each characteristic data. Bivariate analysis aimed to analyze the association of two variables by using SPSS version 22 with chi square test. Multivariate analysis by using multiple logistic regression, aimed to measure the influence among more than one variables.

\section{RESULT \\ A. Univariate Analysis \\ Characteristics of the study subjects which were seen from the age, marital status, edu- cation, working period, VCT clinic practice. VCT clinic environment could be seen in Table \\ 1. Characteristics of the Study Subjects.}

The study was conducted on 142 Female Sex Workers (FSWs) in Grobogan Regency. Data collection was conducted in July 2017. The result of the study showed that most of the FSWs aged between 20-35 years with a total of 124 (87.3\%). Marital status of most FSWs was divorced/widowed with a total of 69 (48.6\%). Education level of most FSWs $<$ High School with a total of 124 (87.3\%).

Working period of most FSWs was 1-2 years old with a total of 58 (40.9\%) and there were 57 FSWs (40.1\%) who had worked less than 1 year. Most of the FSWs committed VCT with a total of 120 (84.5\%) and most of the FSWs committed VCT at hospital with a total of 61 (43.3\%). 
Journal of Health Promotion and Behavior (2017), 2(3): 242-256

https://doi.org/thejhpb.2016.02.03.05

Table 1. Characteristics of the study subjects

\begin{tabular}{llcc}
\hline $\begin{array}{c}\text { Characteristics of } \\
\text { the Subjects }\end{array}$ & Frequency (n) & Percentage (\%) \\
\hline Age & <20 year & 8 & 5.6 \\
& 20-35 year & 124 & 87.3 \\
Marital Status & $\geq 35$ year & 10 & 7.0 \\
& Unmarried & 24 & 16.9 \\
& Married & 49 & 34.5 \\
Education & Divorced/widowed & 69 & 48.6 \\
\multirow{4}{*}{ Working period } & <High School & 124 & 87.3 \\
& > High School & 18 & 12.7 \\
& < 1 year & 57 & 40.1 \\
& 1-2 year & 58 & 40.9 \\
& 2-4 year & 20 & 14.1 \\
VCT Practice & 4-6 year & 6 & 4.2 \\
& $>$ 6 year & 1 & 0.7 \\
Location of VCT & Did not Commit VCT & 22 & 15.5 \\
& Committed VCT & 120 & 84.5 \\
& Private VCT Clinics & 6 & 4.2 \\
& Hospitals & 61 & 43.3 \\
& Puskesmas & 27 & 19.0 \\
& Prison & 1 & 0.7 \\
& Other places & 47 & 33.1 \\
\hline
\end{tabular}

\section{B. Bivariate Analysis}

Bivariate analysis explained about the influence of variable one toward one dependent variable.

Table 2 showed the value of odds ratio was 10.60 it meant that FSWs with good perceived benefit on VCT had 10.60 times bigger possibility to commit VCT than FSWs with insufficient perceived benefit on VCT. The result of Chi-Square test showed that there was an influence of perceived benefit on VCT toward VCT practice and statistically significant $(\mathrm{p}<0.001)$.

The value of odds ratio was 11.39 it meant that FSWs with good attitude from identifying the HIV status had 11.39 times bigger possibility to commit VCT than FSWs with insufficient attitude. The result of Chisquare test showed that there was an influence of attitude from identifying HIV status toward VCT practices and statistically significant $(p<0.001)$.
The value of odds ratio was 22.10 it meant that FSWs with high motivation to follow others had 22.10 times bigger possibility to commit VCT than FSWs with low motivation to follow others. The result of Chi-square test showed that there was an influence of motivation to follow others toward VCT practices and statistically significant $(\mathrm{p}<0.001)$.

The value of odds ratio was 23.80 it meant that FSWs with good support from others had 23.80 times bigger possibility to commit VCT than FSWs insufficient support from others. The result of Chi-square test showed that there was an influence of support from others toward VCT practices and statistically significant ( $\mathrm{p}<0.001$ ).

The value of odds ratio was 9.08 it meant that FSWs with good service practice of VCT clinic had 9.08 times bigger possibility to commit VCT than FSWs with insufficient service practice of VCT clinic. The result of Chi-square test showed that 
there was an influence of service practice of VCT clinic toward VCT practices and statistically significant $(\mathrm{p}<0.001)$.

The value of odds ratio was 32.99 it meant that FSWs with good environment of VCT clinic service had 32.99 times bigger possibility to commit VCT than FSWs with insufficient environment of VCT clinic service. The result of Chi-square test showed that there was an influence of environment of VCT clinic service toward VCT practices and statistically significant $(\mathrm{p}<0.001)$.

Table 2. The result of bivariate analysis on age, occupation, stress level, body mass index, and reproduction organs deviation with female infertility in Dr. Moewardi, Surakarta

\begin{tabular}{|c|c|c|c|c|c|c|c|c|c|}
\hline \multirow{3}{*}{ Variables } & \multicolumn{4}{|c|}{ VCT Practice } & \multirow{2}{*}{\multicolumn{2}{|c|}{ Total }} & \multirow{3}{*}{$\mathbf{O R}$} & \multirow{3}{*}{$95 \% \mathrm{CI}$} & \multirow{3}{*}{$\mathbf{p}$} \\
\hline & \multicolumn{2}{|c|}{ No } & \multicolumn{2}{|c|}{ Yes } & & & & & \\
\hline & $\mathbf{n}$ & $\%$ & $\mathbf{n}$ & $\%$ & $\mathbf{n}$ & $\%$ & & & \\
\hline Perception & & & & & & & & & \\
\hline Not Good & 14 & 45.2 & 17 & 54.8 & 31 & 100 & 10.60 & 3.0010 & $<0.001$ \\
\hline Good & 8 & 7.2 & 103 & 92.8 & 111 & 100 & & & \\
\hline Attitude toward & & & & & & & & & \\
\hline HIV Status & & & & & & & & 4.09 to 31.66 & \\
\hline Not Good & 15 & 44.2 & 19 & 55.8 & 34 & 100 & 11.39 & $4.09003+.00$ & $<0.001$ \\
\hline Good & 7 & 6.5 & 101 & 93.5 & 108 & 100 & & & \\
\hline Motivation & & & & & & & & & \\
\hline Low & 17 & 51.5 & 16 & 48.5 & 33 & 100 & 22.10 & 7.15 to 68.24 & $<0.001$ \\
\hline High & 5 & 4.8 & 104 & 11.5 & 109 & 100 & & & \\
\hline Support & & & & & & & & & \\
\hline Insufficient & 17 & 53.1 & 15 & 46.9 & 32 & 100 & 23.80 & 7.65 to 74.00 & \\
\hline Good & 5 & 4.6 & 105 & 95.6 & 110 & 100 & & & $<0.001$ \\
\hline VCT Clinic & & & & & & & & & \\
\hline Practice & & & & & & & & 3.31 to 24.88 & \\
\hline Insufficient & 12 & 46.2 & 14 & 53.8 & 26 & 100 & 9.08 & $3 \cdot 3+10<4.00$ & $<0.001$ \\
\hline Good & 10 & 8.7 & 106 & 91.3 & 116 & 100 & & & \\
\hline VCT Environment & & & & & & & & & \\
\hline Insufficient & 16 & 64 & 9 & 36 & 25 & 100 & 32.99 & 10.32 to 104.7 & $<0.001$ \\
\hline Good & 6 & 5.2 & 111 & 94.8 & 117 & 100 & & & \\
\hline
\end{tabular}

\section{c. Multivariate Analysis}

Multivariate analysis including independent variables namely perceived benefit on VCT, attitude from the values obtained by identifying HIV status, motivation to follow others, support from others, practice of VCT clinic service, environment of VCT clinic service that were related to dependent variable that is FSW practice to commit VCT in Grobogan Regency could be seen in Table 3.

Based on Table 3 the result of multiple logistic regression on perceived benefit on $\operatorname{VCT}(\mathrm{OR}=10.58$; 95\% $\mathrm{CI}=1.48$ to 76.93 ; $\mathrm{p}=0.019$ ) increased the FSW practice to commit VCT and statistically significant. Attitude and values from indentifying HIV status $(\mathrm{OR}=6.09 ; 95 \% \mathrm{CI}=0.96$ to 38.37 ; $\mathrm{p}=0.054)$ increased the FSW practice to commit VCT even though statistically insignificant.

Motivation from others $(\mathrm{OR}=8.30$; 95\% CI= 1.21 to $56.82 ; \mathrm{p}=0.031)$ increased the FSW practice to commit VCT and statistically significant. Support from others $(\mathrm{OR}=9.45 ; 95 \% \mathrm{CI}=1.46$ to $60.83 ; \mathrm{p}=$ o.018) increased the FSW practice to commit VCT and statistically significant.

Service practice of CVT clinic $(\mathrm{OR}=$ 8.52; $95 \% \mathrm{CI}=1.16$ to $62.32 ; \mathrm{p}=0.035)$ 
increased the FSW practice to commit VCT and statistically significant. Environment of VCT clinic $(\mathrm{OR}=18.91 ; 95 \% \mathrm{CI}=2.59$ to
137.81; $\mathrm{p}=$ 0.004) increased the FSW practice to commit VCT and statistically significant.

Table 3. The result of multiple logistic regression analysis on the influence of perceived benefit, attitude and values from HIV status, motivation from others, support from others, VCT clinic practice, environment of VCT clinic toward FSW practice to commit VCT

\begin{tabular}{lcccc}
\hline \multirow{2}{*}{ Variables } & \multirow{2}{*}{ OR } & \multicolumn{2}{c}{$\mathbf{9 5 \%}$ CI } & \multirow{2}{*}{ p } \\
\cline { 3 - 4 } & & Lower Limit & Upper Limit & \\
\hline Perceived benefit on VCT (good) & 10.58 & 1.48 & 76.93 & 0.019 \\
Attitude and values from HIV & 6.09 & 0.96 & 38.37 & 0.054 \\
Status (good) & 8.30 & 1.21 & 56.82 & 0.031 \\
Motivation(high) & 9.45 & 1.46 & 60.83 & 0.018 \\
Support (good) & 8.52 & 1.16 & 62.32 & 0.035 \\
VCT clinic practice (good) & 18.91 & 2.59 & 137.81 & 0.004 \\
Environment of VCT clinic (good) & 142 & & & \\
N observation & 34.33 & & & \\
-2 log likelihood & $80 \%$ & & & \\
Nagelkerke R ${ }^{2}$ & & & \\
\hline
\end{tabular}

\section{DISCUSSION}

1. The influence of perceived benefit on VCT toward FSW commit VCT

The result of bivariate and multivariate statistic test showed that the was an significant association between perceived benefit on VCT and FSW committed VCT. Some of the FSW had lack of belief on the benefit of VCT and did not commit VCT in the last three months. It can be interpreted that FSWs in Gunung Rejo felt less benefit obtained from committing VCT regularly. One's belief in behavior covers the role of external variables that do not directly appear. FSWs do not commit regular VCT is not only based on health consideration, but it can be based on the same reason (Kartono, 2009).

Belief is often called as factor that is related to one's motivation to conduct an action. Most of FSWs belief on VCT is categorized as good. FSWs have believed that their health is threatened in the next few years if they do not commit VCT. They have believed the severity of the condition if they get infected with HIV. The awareness on the necessity of regular HIV test has occurred in the group.

Clients' perception on the risk of HIV and knowledge on risk behaviors are related to higher level of VCT acceptance (Kawaichai et al, 2002).

Lack of belief turns into the reason why VCT is not committed. A study conducted by Kawichai in 2002-2003 showed that the reason for not commiting HIV test among others are do not have the risk of being infected with HIV and do not clearly understand the VCT service (Kawaichai et $a l, 2007)$. There are some FSWs' incorrect beliefs on VCT, among others are there are many study subjects who believe that their sex behaviors are not at risk and FSWs believe that they are still bale to protect themselves without committing VCT. Reinforcing factor which causes the lack of belief on VCT that comes from FSWs' environment is that FSWs still find their fellow FSWs do not change their risk sexual behaviors after committing VCT (Kartono, 2011). FSWs do not clearly understand the ridk factors of HIV transmission therefore 
they are unaware that they are at risk of getting infected. The wrong perception will generate FSWs do not commit VCT regularly (Widiyanto, 2008).

Furthermore, there are FSWs who still have confidence that they are able to protect themselves without VCT. It happens because of insufficient information dissemination and education to high risk group such as FSWs. FSWs' mobility that always move from one red district to another also makes them lack of the right information on HIV. Incomplete information enables the development of wrong beliefs within themselves (Widiyanto, 2008).

\section{The influence of attitude of values with HIV status toward VCT practice}

Attitude toward behavior is determined by individual belief on behavior which is considered based on evaluation over the result (Mantano, 2002). Individual considers loss or benefit and behave in accordance with the result of their analysis Kartono (2009). In the study, evaluation on the result of VCT result was measured by categorizing values, if FSWs knew their HIV status, into good and not good. The result was there was a significant association between values on knowing their HIV status with the behavior of FSWs in VCT.

PSK who valued good on knowing their HIV status mostly committed VCT in the last 3 months. It can be interpreted that they understand the important consequence that is about to happen if they did not commit VCT regularly. It is in accordance with a study by Solomon in India in 19942002 which stated that the reasons that bring clients to VCT clinic are they realize their risk sexual behaviors, they want to repeat the test to endure the result of the previous test and they have sex partners who are at risk of HIV. In contrast, FSWs who valued that it was not good on knowing their HIV status mostly did not repeat VCT since they did not completely understand the consequence if they were infected with HIV.

It is in accordance with the result of a study by Kawichai in Thailand in 20022003 that one of the reasons of not committing HIV test is do not completely understand the VCT service.

There are several values that are not good among FSWs that should be changed. Among others were knowing the HIV status will not make someone stop doing risk sexual intercourse. The statement showed that after committing VCT, FSWs do not show any changes by reducing the risk behaviors. The improvement of understanding on the reduction of risk behavior should be given to customers and the pimps, so it will help FSWs in doing safe sex practice (Widiyanto, 2008).

Some FSWs also stated that after committing VCT, they will not be able to change the customers' behaviors to conduct safe sex. FSWs do not have enough capability to perform negotiation with the customers to conduct safe sex. FSWs are still worried that they will earn less income if they require the customers to use condom during sex (UNAIDS, 2013; WHO 2013).

Other understanding that needs to be changed on FSWs is there are FSWs who do not consider that committing VCT will be reducing the stigma and discrimination toward people with HIV. FSWs still have perception that HIV and AIDS prevention and countermeasure is individual responsibility, not as an integrated effort so they do not give positive support (Widiyanto, 2008).

The result of multivariate analysis showed that value on knowing their HIV status along with other variables contribute in determining whether they commit VCT. The value represents perception that one believes in certain matter. In health promo- 
tion program, someone is not requested to change the value, but they are requested to recognize the inconsistency between the value they believe and their behavior. Most of FSWs in Gunung Rejo had good value on knowing their HIV status through VCT. However there a lot of FSWs who did not VCT even though they value good on someone knowing their HIV status. FSWs need to recognize further what causes inconsistency between good value in FSWs on knowing her HIV status and FSWs practice to not commit VCT (Abamecha, 2013).

\section{The influence of motivation to follow others toward FSWs commit VCT}

Motivation to follow others' encouragement is a part of subjective norms owned by FSWs. Motivation with encouragement that FSWs obtain to commit VCT, most of the FSW had good motivation to follow the encouragement, that was accomplished by committing VCT practice (Widiyanto, 2008).

In contrast, all FSWs with lack of motivation to follow others' encouragement, did not commit VCT regularly. The almost similar result showed by a study about the search for HIV test at hospital in Chiang Mai Province, North Thailand in 2005-2009. From female group who commit VCT over others' encouragement, $24 \%$ decided not to do HIV test and $18.9 \%$ decided to do HIV test however they did not take the result (Kawaichai, 2002).

The result of bivariate and multivariate statistics analysis supported Theory of Reason Action that the motivation of FSWs to obey others' suggestion to commit VCT would decided FSWs' practice in committing regular VCT. The result of analysis stated that there was a significant association between motivation to follow others' encouragement with FSWs'behavior in committing VCT regularly. The motivation also contributed in determining FSWs' practice not to commit VCT.

Others' encouragement will influence the motivation to commit VCT. In groups of FSWs with low motivation to follow others' encouragement, the encouragement comes from the caretakers in the form of enforcement to commit VCT together with other FSWs, instead, it will not improve FSWs' motivation (Gielen et al., 2002).

FSWs have low motivation to follow the encouragement from the customers, spouse/boy friend and family. The lack of motivation associated with FSWs' lack of respect or appreciation toward the above subjects. FSW' motivation to conduct VCT turns to good if the subjects who give encouragement are the pimpis, health workers, and outreach officers (Gielen et al, 2002; Glanz et al, 2002).

FSWs in Gunung Rejo had positive subjective norm that supported the regular VCT practice. Normative belief of FSWs and motivation to obey what others' wish for establish subjective norms. According to Glanz et al., (2002) all subjects around FSWs encourage to commit VCT and FSWs have motivation to obey after processing information from those subjects. If FSWs obey the subjects' encouragement, they will obtain advantages and appreciation for the action they have conducted (Green, 2005).

The positive reinforcement also bring individuals to join the groups of those subjects who support VCT as one of the prevention of HIV transmission therefore will be able to encourage other individuals to make change by doing regular VCT (Green, 2005).

\section{The influence of others' support toward FSWs commit VCT}

Others' supports measured in the study were the support from the pimps, outreach officers, fellow FSWs, family, health 
workers in VCT clinic, customers and spouses/boyfriends. Most of FSWs who obtained good encouragement, commit VCT regularly. They had positive subjective norm and were motivated to fulfill others' encouragment (Glanz et al, 2002; Mantano et al, 2002).

In Gunung Rejo, there was social rehabilitation caretakers who consisted of some pimps and residents of the area who became the reference for the FSWs. The caretakers had good organization and played very important role in regulating the activities of FSWs, such as counseling and screening for STI that were conducted in the house of the head of Community Association (RT).

The researcher found a conformity in the behavior of FSW in Gunung Rejo in committing regular VCT. Conformity is the turn or change of individual view or action as the result of group pressure that appears for the disagreement between individual opinion and group's opinion (Nasronudin, 2007).

The researcher saw that the caretakers gave enforcement to the FSWs to commit VCT at hospital in groups. the caretakers of social rehabilitation appointed FSWs who were following the counseling at Pak RT's house to leave the venue and went for VCT. The caretakers even provided the transportation to facilitate FSWs.

Based on the researcher's observation, no one of the FSWs dared to refuse the order. The encouragement that is enforcing in nature actually will lead to the loss of initiative among FSWs to scheduled individual VCT. If the caretakers did not order to commit VCT, it is possible that FSWs will not plan to commit regular VCT. The enforcement also neglect the voluntary principle for clients who will conduct counseling and HIV test (Widiyanto, 2008).
Others' support is a reinforcing factor toward the accomplishment of VCT practice by FSWs. During the VCT, FSWs obtain social advantages in the form of social recognition from fellow FSWs, physical advantage by the relieved feeling after obtaining the test result and appreciation from the caretakers in the form of transportation. All those advantages and appreciation are encouraging FSWs to commit VCT regularly (Green, 2005).

Family support is considered not so good by FSWs. Whereas support from other parties aside from family is considered good enough. It is because the FSWs are not being honest to their family about their real job. FSWs also feel insufficient support from the customers. The researchers analyzed that customers' insufficient knowledge on STI lead to lack of concern toward FSWs' health, including the risk of being infected with HIV from the customers.

The supports that keep on arising from the related people will have a magnitude influence toward regular VCT practice. Some have bigger effect than supports from other parties. Among others are supports from fellow FSWs, from pimps, and from health workers (Widiyanto, 2008).

\section{The influence of service practice of VCT clinic toward FSWs commit VCT}

In the study FSWs as the clients of VCT clinics were requested to measure the service practice of VCT clinic they visited. Statistically there was a significant association with FSWs behavior in regular VCT. The result of the study showed that most of FSWs who obtained less sufficient organization practice of VCT clinics, did not commit repeated VCT in the last 3 months.

Some of the FSWs obtained good service practice of VCT clinic. Service practice also contributes in determining the ratio of increasing possibility of not 
Journal of Health Promotion and Behavior (2017), 2(3): 242-256

https://doi.org/thejhpb.2016.02.03.05

committing VCT regularly and FSWs who have less sufficient belief on VCT (Indriani, 2007).

According to FSWs in Gunung Rejo, most of the variables measured in service practice of VCT clinics showed that VCT clinic gave good service to clients. Those variables were fluent process of communication, counselor seldom using language or terms that were not understood by clients, clients were treated nicely by counselor and the service of laboratory officers were friendly during collecting blood. FSWs also stated that the material of pre-test counseling was beneficial for the clients. Almost half the respondents stated that the time needed to meet counselors were relatively time consuming, more than one hour. It happened because they went to visit VCT clinic in groups of 8-10 which were coordinated by the caretakers. Since they came in groups and the limited number of onsite counselors, they had to wait quite long to get the turn.

The duration of waiting period will influence FSWs' motivation to visit VCT clinic in the future. If FSWs wait too long, it will reduce the motivation to come again in the future. To anticipate for not waiting too long, it is suggested for the caretakers not to bring big number of FSWs at a time. The caretakers can suggest the FSWs to utilize the private VCT clinic which is located close to Gunung Rejo.

The less sufficient matter were stated by FSWs that clients obtained discriminative treatment during in VCT clinic, that was generated by their occupation as sexual workers.

The result of qualitative study conducted by Harudin in Yogyakarta in 2007 showed the similar result, that it found several barriers in the implementation VCT among others were clients' waiting time, less empathetic attitude of the officers and there were differences in service toward clients who wanted to conduct HIV test.

Only small part of FSWs felt obtaining discriminative treatment during in VCT clinic, which was generated by their occupation as sex workers. The treatment was not obtained during counseling or HIV test. They obtained different treatment from other general patients during registration. It happened only when they commit VCT at hospital. FSWs were easily distinguished since they came in groups and accompanied by the caretakers of social rehabilitation.

According to Haruddin (2007) the use of less understood language, unfamiliar terms to FSWs will reduce their motivation and makes them to act passively during counseling process, both pre-test and posttest counseling. As the result, the quality of counseling is less sufficient and the communication between counselor and client proceeds only one way.

To overcome the problem it needs the capacity improvement for VCT counselor, especially in facing clients who often conduct counseling in CVT clinic, to avoid clients' boredom. The service practice of VCT clinic that needs to be improved are there are clients who get different counselors for pre-test and post-test counseling, it generates FSWs spend longer time at CVT clinic and leads to boredom for the clients. The management of CVT clinic should be able to ensure that counselors actually have enough time to perform counseling with clients and do not perform double tasks.

Most of the clients in the study stated that they received the result of HIV test on the same day. In VCT service scheme, while clients are in waiting room, clients have been informed about the CVT procedures, including the option to wait for 2 hours to get the result on the same day. The level of acceptance is quite high toward VCT clinic that provides express HIV test and the 
result can be fetched on the same day (Lai et al, 2016).

A few of the clients took the result on the other day. It was possibly because of clients' unpreparedness in receiving the test result, both for reactive and non-reactive result, clients were not ready with any plan after getting the HIV test result and clients did not feel the support from family and friends. Another reason is related to the model of transportation they used to get to the clinic. Since they came together in group, the FSWs who got the last turn did not take the result on the same day since their friends and caretaker were waiting to go home together.

\section{The influence of the environment of VCT clinic toward FSW commit VCT}

Most of the variables measured in the service environment of VCT clinic showed that VCT clinic had given good service place to clients. Most FSWs stated that the VST location they visited was comfortable, providing procedure information/ counseling scheme for clients, the VCT location ensuring clients' confident and the information confidentiality was maintained. Counseling and testing facilities in CVT clinic were quite complete, and it was presented with posters, leaflets, brochures about STI, HIV and AIDS, as well as safe sex. Educational materials in the counseling room of VCT clinic were considered quite complete, and it was represented with the availability of condom, penis model, syringe model, and pictures of opportunistic infection.

In general, the organizational environment of VCT clinic visited the clients already had facilities that supported VCT service in accordance with Minister of Health's Stipulation No. 1507/Menkes/ $\mathrm{SK} / \mathrm{X} / \mathrm{O5}$, even though there were atill some points that were sensed less sufficient. Among others were there was no information scheme or counseling procedures which was clear enough for the patients. Some of the FSWs used the same door to enter counseling room and also as the exit door after committing VCT. It would remove client privacy principles since it was possible to meet other clients who were waiting to see the counselor. It can be used as the input for the management of VCT clinic to arrange the clinic's rooms in such a way that will not reduce client privacy principles. According to Green (2005) the condition of the environment will facilitate whether or not an individual will do an action. If the condition of VCT clinic environment turns to barrier for the clients since they feel their privacy is not maintained, it possible will reduce the motivation of FSWs to come again. Environmental change in the form of VCT clinic arrangement may improve FSWs participation as the clients, in HIV prevention and countermeasure.

Based on the result of the study above, it can be concluded that FSWs' practice in committing VCT is influenced by perceived benefit on VCT, motivation from others, support from others, service practice of VCT clinic, service environment of VCT clinic and statistically significant. Attitude and values on knowing HIV status also influence and it is statistically insignificant.

\section{REFERENCE}

Abamecha F, Godesso A, Girma E (2013). Intention to Voluntary HIV Counseling And Testing (VCT) Among Health Professionals In Jimma Zone, Ethiopia: The Theory of Planned Behavior (TPB) Perspective. BMC Public Health. 13 (140): 1-7.

Alao SA (2004). Knowledge and attitude towards HIV/AIDS among students of 
Journal of Health Promotion and Behavior (2017), 2(3): 242-256

https://doi.org/thejhpb.2016.02.03.05

tertiary institutions in Ilorin metropolis.

Alkan ML, Akinwande OA (2010). HIV Voluntary Counseling and Testing (VCT) in Three Sites in Nigeria. Journal International Congress on Infectious Diseases (ICID). 1-10.

Chege PM, Muthamia OG (2017). Level of Micronutrient Supplements Uptake Among People Living with HIV/AIDS In Kayole, Nairobi County, Kenya. Journal of AIDS and HIV Research. (9): 74-97.

Departemen Kesehatan RI (2004). Modul Pelatihan Konseling dan Tes Sukarelawan HIV (Voluntary Counselling and Testing $=$ VCT).

Family Health International (2004). HIV Voluntary Counseling and Testing: A Reference Guide for Counselors and Trainers.

Fatmala, Risanita D (2016). Faktor Predisposing, Enabling dan Reinforcing dalam pemanfaatan VCT oleh lakilaki Seks dengan Laki-laki (LSL). Jurnal Kesehatan Masyarakat. (4): 138-150.

Gielen AC, McDonald EM (2002). Using The Precede-Proceed Planning Model To Apply Health Behavior Theories. Dalam: Glanz, K., Rimer B.K., Lewis, F.M. Health behavior and health education: theory, research, and practice. 3rd edition. Jossey-Bass. San Fransisco.

Glanz K, Rimer BK, Lewis FM (2002). Health Behavior and Health Education: theory, research, and practice. 3rd edition. Jssey Bass. San Franssisco.

Green L, Kreuter M (2005). Health Program Planning an A Diagnostic Approach Fourth Edition. California: McGraw-Hill Companies.
Indriani D (2007). Perilaku Pemanfaatan skrining IMS oleh WPS Resosialisasi Argorejo dalam pencegahan HIV dan AIDS di klinik Griya ASA PKBI Kota Semarang. Semarang: Fakultas Ilmu Kesehatan Universitas Dian Nuswantoro.

Haruddin, Hasanbasri, Woerjandari A (2007). Studi pelaksanaan HIV Voluntary Counseling And Testing (VCT) di RSUP Dr. Sardjito Yogyakarta. Working Paper Series No. 3, Program Magister Kebijakan dan Manajemen Pelayanan Kesehatan, Universitas Gadjah Mada, Yogyakarta.

Kartono (2009). Psikologi Abnormal dan Abnormalitas Seksual. Bandung: CV Mandar Maju.

(2011). Patologi Sosial. Jakarta: PT. Radja Grafindo Persada.

Kawichai S, Celentano DD, Chariyalertsak S (2007). Community-based Voluntary Counseling and Testing Services in rural communities of Chiang Mai Province, Northern Thailand. AIDS Behavior. (11): 770-777.

Kawichai S, Celentano DD, Chaifongsri R. (2002). Profiles of HIV Voluntary Counseling and Testing of clients at a district hospital, Chiang Mai Province, Northern Thailand, from 1995 to 1999. Journal of Acquired Immune Deficiency Syndromes. (30): 493-502.

Kemenkes RI (2014). Situasi dan Analisis HIV AIDS Pusat data dan Informasi Kementerian Kesehatan RI. http://www.depkes.go.id/resources/downlo ad/pusdatin/infodatin/Infodatin\%20 AIDS.pdf. Diakses 6 Januari 2017.

Kemenkes RI. (2016). Laporan Kasus HIV/ AIDS di Indonesia sampai dengan Desember 2016. http:// spiritia.or.id/ Stats/detailstat.php?no=7. Diakses 8 Februari 2017. 
Komisi Penanggulangan AIDS Nasional. (2009). Kebijakan Nasional dalam Penanggulangan HIV/ AIDS. Jakarta.

Lai CC, Liu WC, Fang CT, Yang JY, Chang LH, Wu PY, Luo YZ, Chang SF, Su YC, Chang SY, Hung CC (2016). Transmitted Drug Resistance of HIV-1 Strains Among Individuals Attending Voluntary Counselling and Testing In Taiwan. Journal of Antimicrobial Chemotherapy. (71): 226-234.

Montano, Daniel E, Kasprzyk D (2002). The theory of reasoned action and the theory of planned behavior. San Fransisco: Health Behavior anda Health Education.

Mubarokah K (2006). Teknik negosisiasi WPS (Wanita penjaja Seks) dalam mengajak klien memakai kondom: studi kualitatif upaya pencegahan HIV/AIDS di lokalisasi Sunan Kuning Semarang. Fakultas Kesehatan Masyarakat Universitas Diponogoro. Semarang

Murti B (2013). Prinsip dan metode riset epidemiologi. Edisi kedua, jilid pertama. Gadjah Mada University Press. Yogyakarta.

Nasronudin (2007). HIV dan AIDS. Pendekatan Biologi Molekuler, Klinis dan Sosial. Ailangga University Press. Surabaya

Onokerhoraye AG, Maticka-Tyndale E (2012). HIV prevention for rural youth in Nigeria: background over- view. African Journal of Reproductive Health. 16: 25-38.

Peraturan Daerah Kabupaten Grobogan Nomor 4 (2014). Penanggulangan HIV dan AIDS.

Solomon S, Kouyoumdijan FG, Cecelia AJ (2006) Why are People Getting Tested? Self-Reported Reasons for Seeking Voluntary Counseling and Testing at a Clinic in Chennai, India. AIDS and Behavior. 10 (4): 415-420.

Spiritia (2011). Peran dukungan sebaya terhadap peningkatan mutu hidup ODHA di Indonesia. http://spiritia. or.id/dokumen/laporan-penelitianperan dukungan-sebaya.pdf. Diakses tanggal 27 Januri 2017.

UNAIDS (2013). Position Statement on Condom and HIV Prevention. http://data.unaids.org/una-docs/condompolicy_julo4_en.pdf. Diakses tanggal 20 November 2016.

WHO (2013). AIDS Prevention and Control, Presentations on World Summit of Ministers of Health on Program for AIDS Prevention. London.

Widiyanto SG (2008). Faktor-faktor yang Berhubungan dengan Praktik Wanita Pekerja Seks (WPS)dalam VCT Ulang di Lokalisasi Sunan Kuning Semarang. Jurnal Kesehatan Masyarakat. 1-170. 